\title{
A study on manufacturing of red ginseng Makgeolli using the red ginseng starch and changes of physicochemical components of red ginseng Makgeolli during storage periods
}

\author{
Hwan Lee ${ }^{1}$, Yeong-Su Kim ${ }^{1}$, Do-Yeon Kim ${ }^{1}$, So-Young Kim ${ }^{2}$, Wan-Kyu Lee ${ }^{3}$, \\ Sang-Myeong Lee ${ }^{4}$, Jong-Dae Park ${ }^{1}$, Mi-Yae Shon ${ }^{1 *}$ \\ ${ }^{1}$ International Ginseng and Herb Research Institute, Geumsan 312-804, Korea \\ ${ }^{2}$ Functional Food and Nutrition Division Department of Agrofood Resources, National Academy of Agricultural Sciences \\ (NAAS), RDA, Suwon 441-853, Korea \\ ${ }^{3}$ College of Veterinary Medicine, Chungbuk National University, Cheongju 361-763, Korea \\ ${ }^{4}$ Devision of Biotechnology, College of Environmental and Bioresource Sciences, \\ Chonbuk National University, Iksan 570-752, Korea
}

\section{홍삼 전분을 이용한 홍삼막걸리의 제조 및 이화학적 성분 변화}

\author{
이환 ${ }^{1} \cdot$ 김영수 $^{1} \cdot$ 김도연 $^{1} \cdot$ 김소영 $^{2} \cdot$ 이완규 $^{3} \cdot$ 이상명 $^{4} \cdot$ 박종대 $^{1} \cdot$ 손미례 $^{1 *}$ \\ ${ }^{1}$ (재단법인) 금산국제인삼약초연구소, ${ }^{2}$ 농촌진흥청 기능성식품과 \\ ${ }^{3}$ 충북대학교 수의학과, ${ }^{4}$ 전북대학교 환경생명자원대학 생명공학부
}

\begin{abstract}
This study was performed to develop the maufacturing processes of Makgeolli using red ginseng starch (RGS). After the fermentation of RGS with koji, nuruk, and yeast, the different temperature effects on the number of the yeast cells, the content of organic acid, free sugars, and total acid, and $\mathrm{pH}$ were investigated. There were no changes in the composition of the yeast cell number and content of organic acid amd during 20 days at $4^{\circ} \mathrm{C}$. The content of free sugars (sucrose, glucose and mannose) and the $\mathrm{pH}$ value of red ginseng Makgeolli decreased during storage at $4^{\circ} \mathrm{C}$. This meant that the total acid content and $\mathrm{pH}$ value increased after organic acid was produced from fermentation. Therefore, red ginseng Makgeolli is highly acidic and sour. Since high acidity helps improve storage conditions, so this developed red ginseng Makgeolli is considered safe for consumption. Furthermore, the total content of ginsenoside was $2.47 \mathrm{mg} / \mathrm{mL}$, which was differentiate Makgeolli using red ginseng starch, with others. Therefore, new red ginseng Makgeolli is rich in organic acid, free sugars, and ginsenoside. As a result, its storage, taste, and flavor improved.
\end{abstract}

Key words : red ginseng starch, red ginseng Makgeolli, organic acid, free sugars, ginsenoside.

\section{서 론}

*Corresponding author. E-mail : nuruksmy@ginherb.re.kr Phone : 82-41-750-1661, Fax : 82-41-750-1629

Received 8 October 2014; Revised 13 April 2015; Accepted 15 June 2015.

Copyright (c) The Korean Society of Food Preservation. All rights reserved.
최근에 웰빙이나 lifestyles of health and sustainability (LOHAS) 트렌드가 확산됨에 따라 민족 고유의 전통주에 관심이 높아지면서 특유의 향미와 낮은 알코올 함량의 혼탁 한 술인 막걸리는 새로운 전환기를 맞이하고 있다 $(1,2)$. 술 은 인류 역사와 함께 탄생한 것으로 지역, 민족, 기후, 풍토 에 따라 주조법이 다양하고 독특하게 발달됨에 따라서 각 민족의 고유한 전통주로서 발전하였다. 막걸리는 찹쌀, 멥 쌀 등의 전분질을 원료로 하고, 발효제로서 누룩을 첨가하 
여 병행 복발효시킨 술덧을 혼탁하게 제성한 우리나라 고유 의 전통주이다 $(3,4)$. 우리나라의 막걸리는 곡물을 누룩과 발효하고 여과하지 않고 효모나 유산균 등을 포함하는 발효 산물 전체를 음용하는 술로서, 알코올이 상대적으로 낮아 위에 부담이 적고 각종 유용한 영양소와 인체 내 신진대사 에 관여하는 필수 아미노산을 함유하고 있는 것으로 보고되 어 있다(5-8). 또한 풍미물질인 ethylacetate 및 amylacetate, ethylcaproate 등의 ester(9)와 간 기능을 도와주는 acetylcholine 등이 함유되어 있으며(10,11), 최근에는 4hydroxybenzaldehyde, 2-(4-hydroxylphenyl) ethanol(tyrosol), trans-ferulic acid, cis-ferulic acid 및 $1 \mathrm{H}$-indole-3-ethanol (tryptophol) 등의 항 산화 물질을 막걸리로부터 분리하여 발표(12)하였다.

본 연구에 사용한 홍삼의 원재료인 인삼(Panax ginseng C.A Meyer)은 쌍떡잎식물 산형화목 두릅나무과의 여러해 살이풀로 불로장생의 영약으로 알려져 있고 오랜 세월동안 사용되어왔으며, 최근에는 건강기능식품으로써 각광을 받 고 있는 식품이다. 또한 한약중에서도 최고의 약재로 꼽히 며 한방의서인 '神農本草經'(신농본초경)에 인삼은 간장, 심 장, 폐장, 신장, 비장의 양기를 돋우고 정신을 안정시킨다고 알려져 있다. 홍삼은 인삼을 쪄서 말린 제품으로 증숙시 수삼에는 없는 ginsenoside Rg2 Rg3 Rg5 Rk1 등의 희소 진세노사이드 성분들을 포함하고 있으며 이 희소 진세노사 이드는 각종 질병의 예방과 치료에 탁월한 효과를 나타낼 뿐만 아니라 병이 없는 사람들에게는 힘과 활력을 주는 강장제로서 광범위한 약효를 나타내며 장기간 사용하여도 부작용이 없다고 알려져 있다. 주요 효능으로는 면역증강, 혈행개선, 기억력 증진, 항염 및 항암효과 등이 보고되고 있다 $(13,14)$. 홍삼전분은 홍삼농축액을 만드는 과정에서 생 성되는 불용성 성분으로 사용되지 않는 자원으로써 홍삼의 진세노사이드를 포함하고 있는 면역 기능을 가진 우수한 원료로 사용이 가능한 물질(15)이다. 또한 이 홍삼전분은 유기산과 유리당 진세노사이드 등을 포함하고 있어 효모의 증식에 유익한 원료로 사용될 수 있는 조건을 갖추고 있다.

따라서 본 연구에서는 홍삼전분을 이용한 새로운 홍삼막 걸리를 제조하여 진세노사이드 함량, 유기산, 유리당, 효모 수, PH 및 총산 등을 분석하였다.

\section{재료 및 방법}

\section{실험재료}

홍삼 막걸리 제조에 사용된 홍삼 전분은 홍삼농축액 제 조과정에서 발생하는 홍삼 추출액에서 가라앉은 불용성 성분을 수거하여 원심분리 후 페이스트 상태로 제조한 형태 이다. 본 연구에 사용된 홍삼 전분은 충청남도 금산군 소재 의 성신비에스티(주)에서 제 공받아 사용하였으며 $-20^{\circ} \mathrm{C}$ 에서 냉동보관하면서 홍삼막걸리 제조에 사용하였다.

\section{홍삼막걸리 제조}

홍삼전분을 이용한 막걸리의 제조 방법은 Fig. 1 과 같이 진행되었다(16). 홍삼막걸리는 전통적인 발효방법에 홍삼 전분 $2 \%, 5 \%, 7 \%$ 를 첨가하여 제조한 후 제품의 색과 맛을 측정하여 관능적인 요소가 가장 좋은 농도의 홍삼막걸리를 제조하여 실험에 사용하였다. $23 \sim 25^{\circ} \mathrm{C}$ 에서 2 일간 배양하여 밑술을 제조하고 1 단 담금은 밑술에 $2 \%$ 홍삼전분, 입국, 건조효모, 누룩을 넣고 잘 혼합하여 증류수를 넣고 3 4일간 발효하였다. 2 단 담금은 1 단 담금 발효액에 호화미 $300 \mathrm{~g}$ 과 누룩 $40 \mathrm{~g}$ 을 잘 혼합한 후에 증류수 $1,200 \mathrm{~mL}$ 를 첨가하여 3 4일간 발효하여 제조하였다. 제조한 술을 주정계(AL-21 a, ATAGO, Tokyo, Japan)로 알코올 도수를 측정하여 $12 \sim 13^{\circ}$ 이면 여과하여 아스파탐과 증류수를 첨가하여 알코 올 도수가 $6^{\circ}$ 로 조정한 후 3 일 동안 $23 \sim 25^{\circ} \mathrm{C}$ 에서 숙성하여 최종적으로 알코올 도수가 $6^{\circ}$ 인 홍삼막걸리를 제조하여 시료 실험을 위한 시료를 준비하였다.

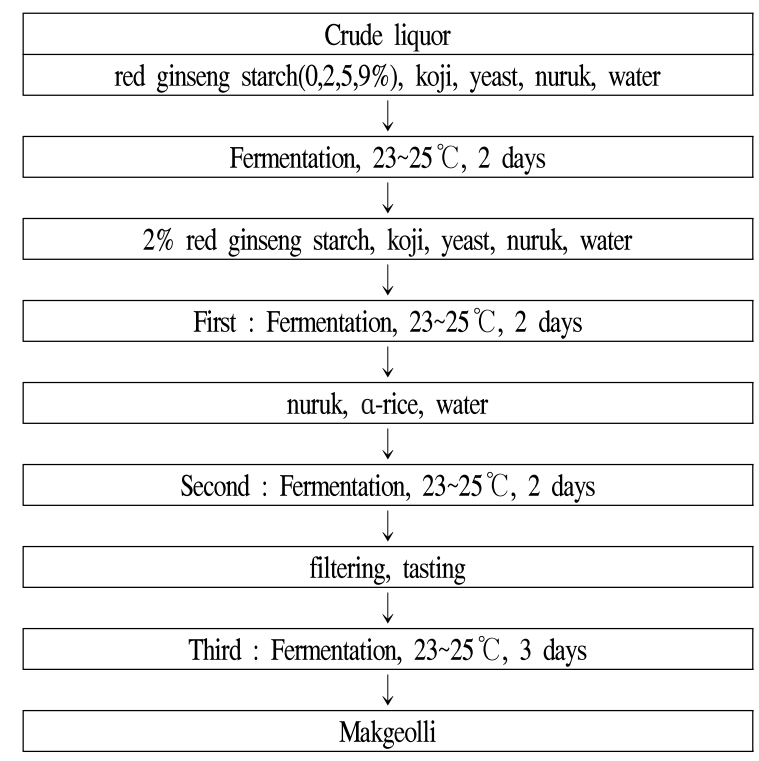

Fig. 1. A flow diagram of the red ginseng Makgeolli preparation.

\section{관능평가}

관능평가는 전통적인 발효방법에 홍삼전분 $0 \%, 2 \%, 5 \%$, $7 \%$ 를 첨가하여 제조한 후 막걸리의 관능성에 미치는 영향 을 평가하기 위하여 제품의 색(color), 풍미(flavor), 맛 (taste), 종합적 기호도(overall acceptability)를 조사하였다. 최저 1점, 최고 7점으로 7단계 기호도 척도법으로 실시하여 관능적인 요소가 가장 좋은 농도의 홍삼막걸리를 제조하여 실험에 사용하였다. 관능검사원은 다양한 기호도를 평가하 기 위하여 특별히 선발된 금산 관내 거주자 30 인을 대상으 로 실시하였다.

\section{효모계수}

균일하게 혼합된 시료 $1 \mathrm{~mL}$ 를 무균적으로 취하여 멸균 
PBS 용액(pH7.4)에 계단 희석하고, 각 희석액 $100 \mu \mathrm{L}$ 를 $1 \%$ L-tartaric acid(Sigma-Aldrich, USA)가 함유된 potato dextrose $\operatorname{agar}(\mathrm{pH} 3.5 \pm 0.1)$ 평판배지에 접종하여 $25^{\circ} \mathrm{C}$ 에서 2 일 동안 배양한 후 생성된 콜로니를 계수하였으며 결과는 평균값 \pm 표준편차로 나타내었다.

\section{유기산, 유리당 및 에탄올 분석}

유기산, 유리당 및 에탄올 분석을 위해 균일하게 혼합된 시료를 $12,000 \mathrm{rpm}$ 에서 10 분간 원심분리한 후, 상등액을 취하여 $0.2 \mu \mathrm{m}$ membrane filter로 여과하여 Sep-pak $\mathrm{C}_{18}$ cartridge에 통과시켜 불순물을 제거한 후 분석을 위한 시료 로 사용하였다. 유기산 분석은 $\operatorname{Sim}$ 등(17)의 방법에 따라 전 처리한 시료를 HPLC(Agilent 2690, Technologies, Santa Clara, CA, USA)를 사용하여 분석하였고 컬럼은 $\mathrm{ODS}$ column(Prevail Organic Acid, $4.6 \mathrm{~mm} \times 150 \mathrm{~mm}$, Alltech Grace Co., Deerfield, IL, USA), 이동상은 $0.25 \mathrm{mM}$ phosphate buffer를 사용하였으며 유속은 $0.3 \mathrm{~mL} / \mathrm{min}$ 로 UV detector를 이용하여 $210 \mathrm{~nm}$ 에서 분석 하였다. 유리당 분석 은 Hur 등(18)의 방법에 따라 전 처리한 시료를 HPLC(Agilent 2690, Technologies, USA), detector는 RID를 사용하여 분석하였고 컬럼은 Supelcogel $\mathrm{Ca}(7.8 \mathrm{~mm} \times 300$ $\mathrm{mm}$, Sigma-Aldrich, St. Louis, MO, USA), 이동상은 3차 증류수를 사용하였으며 유속은 $0.5 \mathrm{~mL} / \mathrm{min}$ 의 조건으로 분 석하였다. 각 유기산 및 유리당 표준물질을 제조하여 표준 곡선을 작성하여 유기산 및 유리당을 정량하였다. 에탄올 함량은 $0.45 \mu \mathrm{m}$ membrane filter를 사용하여 여과한 시료를 DB-ALC2 column(30 m×0.53 mm, $2 \mu \mathrm{m}$ film thickness: Agilent, Folsom, USA) 이 장착된 $\mathrm{GC}(6890 \mathrm{~N}$, Hewlett Packard, Palo Alto, USA)를 이용하여 oven $70^{\circ} \mathrm{C}$, injector $200^{\circ} \mathrm{C}$ 그리고 detector $250^{\circ} \mathrm{C}$ 에서 정량 분석하였다.

\section{$\mathrm{pH}$ 및 총산 분석}

수소이온농도는 시료 $100 \mathrm{~mL}$ 를 취하여 $\mathrm{pH}$ meter (Thermo Electron Co., MA, USA)를 이용하여 측정하였으 며, 총산은 시료 $10 \mathrm{~mL}$ 에 증류수를 가하여 $100 \mathrm{~mL}$ 로 정용 한 후, 지시약으로 $1 \%$ phenolphthalein을 사용하여 $0.1 \mathrm{~N}$
$\mathrm{NaOH}$ 로 미적색 $(\mathrm{pH}$ 8.3)이 될 때까지 적정하였다. 적정에 소비된 $\mathrm{NaOH}$ 소비량에 0.009 을 곱하여 시료 중의 산을 lactic acid의 양으로 환산(18)하였으며 실험은 세 번 반복, 결과는 평균값 \pm 표준편차로 나타내었다.

$$
\begin{aligned}
\text { 총산 }(\% \text { 젖산 })= & 0.009 \times \mathrm{NaOH} \text { 소비량 }(\mathrm{mL}) \times \mathrm{NaOH} \text { 역가/시 } \\
& \text { 료의 부피 } \times 100
\end{aligned}
$$

\section{진세노사이드 분석}

Ginsenoside 함량은 HPLC(2690, Agilent, Technologies, $\mathrm{USA})$ 을 이용하여 측정하였으며, $\mu$-Bondapak $\mathrm{C}_{18}(3.9 \mathrm{~mm} \times$ $150 \mathrm{~mm}, 5 \mu \mathrm{m})$ column을 사용하여 $70 \%$ acetonitrile을 이동 상으로 사용 하였다. 이동상의 유속과 컬럼 온도는 각각 $0.6 \mathrm{~mL} / \mathrm{min}, 43^{\circ} \mathrm{C}$ 로 하고, $\mathrm{UV}$ 검출기의 검출 파장은 203 $\mathrm{nm}$ 로 하여 분석하였다.

\section{통계처리}

본 실험에서 얻어진 통계분석 결과는 SPSS(Statistical Package for Social Science)를 이용해서 통계 분석하였다. 실험군당 평균 \pm 표준오차로 표시하였고, 그룹간 평균차에 대한 통계적 유의성을 검정하기 위해 일원배치 분산분석 (one-way analysis of variance)을 실시 한 후 $\mathrm{p}<0.05$ 수준에 서 Tukey's test를 이용한 사후 검정(Post-Hoc test)을 실시하 였다.

\section{결과 및 고찰}

\section{홍삼전분 막걸리 제조 및 관능평가}

홍삼 전분은 홍삼 농축액 제조 시 발생하는 부산물로 홍삼액 추출 중 침강되는 불용성 성분으로 진세노사이드, 총 페놀, 조단백, 유리당 및 전분 함량이 각각 $2.7 \mathrm{mg} / \mathrm{g}$, $15.4 \mathrm{mg} / \mathrm{g}, 11.8 \%, 2.4 \mathrm{mg} / \mathrm{g}$, 그리고 $53 \%$ 함유하고 있어(15) 다양한 분야에 기능성 소재로의 응용 가능성이 높은 물질이 다. 홍삼 전분을 이용하여 Fig. 1과 같은 과정을 통해 최종 알코올 함량을 $6 \%$ 의 막걸리를 제조 하였고 관능 평가 및

Table 1. Sensory evaluation of Makgeolli with varying amountsl of red ginseng starch

\begin{tabular}{lcccc}
\hline & Control & Red ginseng starch & Red ginseng starch & \multicolumn{2}{c}{ Red ginseng starch } \\
$9 \%$
\end{tabular}

\footnotetext{
${ }^{1)}$ Values were expressed as the mean $\pm \mathrm{SD}(\mathrm{n}=30)$.

${ }^{2)} 7$ Point Likert scale : 1-extremely dislike, 7-extremely like.
} 
실험에 사용 하였다. 홍삼전분을 $2 \%$ 첨가한 막걸리의 맛 (6.21), 향(5.75), 전체적인 평가(6.11)에서 높은 기호도를 보였고, $9 \%$ 홍삼전분 첨가 막걸리가 낮은 기호도를 나타내 었는데, 이는 홍삼의 쓴맛이 강하게 작용하여 기호도에 부 정적인 영향을 미친 것으로 판단된다. 이상의 결과 맛과 향미, 전체적인 기호도에서 높은 값을 나타낸 홍삼전분 $2 \%$ 첨가 막걸리의 진세노사이드 분석 및 유기산, 유리당, 총산, $\mathrm{PH}$ 분석 등의 실험에 사용하였다(Table 1).

\section{효모계수}

각 저장 온도에서 시간경과에 따른 막걸리 속 효모수의 변화는 Fig. 2 에서 보는 바와 같다. $4^{\circ} \mathrm{C}$ 에서 저장한 경우, 저장 4 일부터 효모수가 감소하기 시작하였으며, 그 이후 감소는 완만하게 진행되었다. 저장 20 일경 $3.5 \times 10^{8}$ $\mathrm{CFU} / \mathrm{mL}$ 을 나타내었다. 그러나 $25^{\circ} \mathrm{C}$ 에서 저장한 경우, 저장 12 일까지 효모수가 지속적으로 감소하여 $2.7 \times 10^{8} \mathrm{CFU} / \mathrm{mL}$ 로 나타났으며, 20 일경 효모수는 $1.2 \times 10^{8} \mathrm{CFU} / \mathrm{mL}$ 로 $4^{\circ} \mathrm{C}$ 에
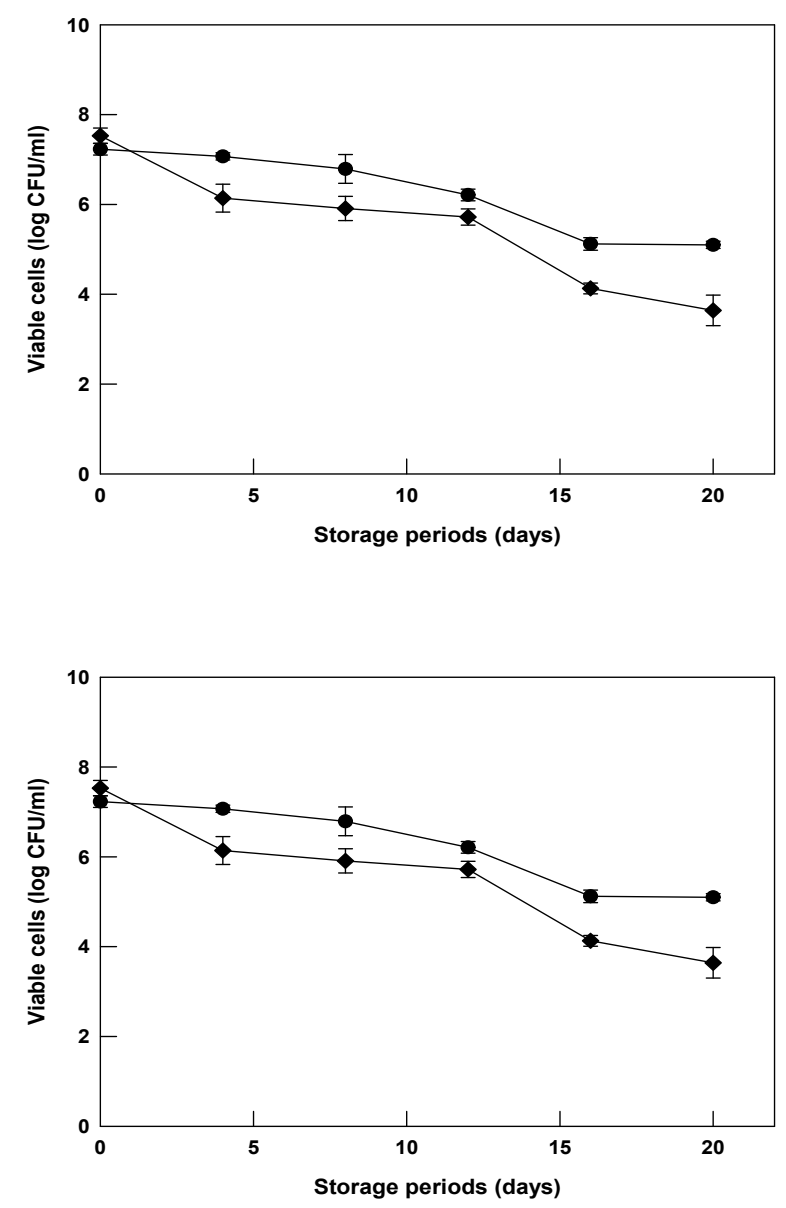

Fig. 2. Changes in yeast viable cell counts of $2 \%$ red ginseng Makgeolli during storage at $4{ }^{\circ} \mathrm{C}(\boldsymbol{)})$ and $25^{\circ} \mathrm{C}(\diamond)$.

Values with varying superscripts in the same row are significantly different $(\mathrm{p}<0.05)$ among groups in Tukey's test.
서 보존한 것보다 훨씬 적었다. $4^{\circ} \mathrm{C}$ 저장보다 $25^{\circ} \mathrm{C}$ 저장에서 효모수가 더 감소한 것은 높은 온도에서 자기소화가 더 많이 진행되어 죽은 균수가 증가한 것으로 사료된다. 또한 효모수가 완만한 감소를 보이는 이유는 효모의 경우 알콜 내성이 있는 Saccharomyces cerevisiae등 비교적 단순한 종 류의 효모들만이 함유되어 있기 때문인 것으로 사료된다. 발효 초기에는 누룩에서 유래한 일반세균, 곰팡이, 효모가 공생관계에 있다가 젖산이 생성되어 산성화되고 효모만이 대량으로 증가하는 것으로 보고되었다(20).

\section{유기산 분석}

홍삼전분을 이용한 막걸리에서는 lactic $\operatorname{acid}(4.16 \mathrm{mg} / \mathrm{mL})$, citric $\operatorname{acid}(0.88 \mathrm{mg} / \mathrm{mL})$, malic $\operatorname{acid}(0.39 \mathrm{mg} / \mathrm{mL})$ 등의 유기산 이 풍부한 것으로 확인 되었다(Table 2). Lactic acid의 경우 막걸리 발효에서 malo-lactic fermentation의 경로에서 알콜 발효후 Lactobacillus sp. 와 Leuconostoc sp. 등과 같은 특정 유산균에 의해서 일어나는 발효서 이로 인하여 malic acid가 lactic acid로 전환된다. 유기산은 술에서 신맛을 내는 성분 으로 소량이 존재할 경우 맛과 향을 높이는 역할을 하지만 acetic acid 함량이 다량 존재할 경우 알코올 성분의 산화로 초산 발효단계로 진행되어 주질을 저하시키는 요인이 된다 고 알려져 있다 $(1,21)$. 막걸리 저장 중에 위와 같은 발효가 적절히 이루어지면 acetic acid의 감소로 풍미가 개선되고 발효 중 미생물학적 안정성을 높여주는 긍정적인 효과를 제공하며 주질의 부드러움과 입에서 느껴지는 촉감을 강화 시켜주며 하는 역할을 한다. 저장 초기에는 malic acid의 함량이 $4^{\circ} \mathrm{C}$ 및 $25^{\circ} \mathrm{C}$ 에서 $0.39 \mathrm{mg} / \mathrm{mL}$ 와 $0.58 \mathrm{mg} / \mathrm{mL}$ 이었으 나 20 일이 경과한 저장일에는 $0.46 \mathrm{mg} / \mathrm{mL}$ 그리고 0.17 $\mathrm{mg} / \mathrm{mL}$ 으로 측정되었다. 이것은 $25^{\circ} \mathrm{C}$ 에서는 유산균등의 활 발한 발효에 의해서 malic acid가 lactic acid로 전환되었기 때문이며 $4^{\circ} \mathrm{C}$ 에서는 온도에 따른 malo-lactic fermentation 진행 정도의 차이로 판단된다. 즉 냉장 유통되는 제품의 경우 낮은 온도로 인해 이와 연관된 유산균의 생육이 지체 되어 malo-lactic fermentation이 다소 지연됨으로써 malic acid함량이 유지되는 것으로 사료된다. 막걸리 제조 후, 저 장온도 $\left(4^{\circ} \mathrm{C}\right.$ 및 $\left.25^{\circ} \mathrm{C}\right)$ 및 저장기간에 따라 생성된 유기산의 농도 변화는 Table 2에서 보는 바와 같다. $4^{\circ} \mathrm{C}$ 에서 저장 시, 일반적인 유통기간( 10 일)보다 긴 20 일 동안 유기산의 변화를 관찰하였다.

\section{유리당 분석}

홍삼전분을 이용한 막걸리의 유리당 분석 결과 glucose 가 $4.4 \mathrm{mg} / \mathrm{mL}$, sucrose $2.8 \mathrm{mg} / \mathrm{mL}$ 그리고 mannose 1.4 $\mathrm{mg} / \mathrm{mL}$ 으로 막걸리의 주 구성당으로 측정되었는데 이는 Lee 등(25)의 쌀누룩을 이용한 탁주에서 glucose의 함량이 가장 높게 나타난 연구결과와 일치하였다. 이들 성분들은 주로 환원당으로 알콜 발효의 기질로 사용되고 산미, 감칠 
맛 등과 조화되어 막걸리의 독특한 맛을 제공 한다. 또한 환원당을 포함하고 있는 홍삼 전분은 당화 amylase작용에 의해서 큰 전분 분자가 작은 전분 분자로 분해되고 다시 glucose등과 같은 환원당으로 분해되고 분해된 환원당은 알콜 발효의 기질로 이용되는 주요 성분으로 작용한다. 저 장 4 8일 이후부터는 당이 급격히 감소하였으며 8일 이후 부터는 큰 차이를 보이지 않았는데 이는 저장 중 당분이 알콜과 탄산가스로 분해되었기 때문인 것으로 여겨진다. 막걸리 제조 후, 저장온도 $\left(4^{\circ} \mathrm{C}\right.$ 및 $\left.25^{\circ} \mathrm{C}\right)$ 및 저장기간에 따라
생성된 유리당의 농도 변화는 Table 3에서 보는 바와 같다. $4{ }^{\circ} \mathrm{C}$ 에서 저장시, 일반적인 유통기간보다 $(10$ 일) 긴 20 일 동 안 유리당의 변화를 관찰하였으며 유리당은 12 일 경에 sucrose, glucose와 mannose의 양은 $1 / 2$ 으로 감소하였다. 또 한 20 일 경에는 $1 / 3.5$ 로 감소하였으며, $25^{\circ} \mathrm{C}$ 에서 저장 시, 4 일째부터 감소하여 12 일 경에는 당이 측정되지 않았다.

\section{$\mathrm{pH}$ 및 총산 분석}

막걸리의 저장온도 및 저장기간에 따른 $\mathrm{pH}$ 및 총산의

Table 2. Change in the amount of organic acid in Makgeolli during storage at $4{ }^{\circ} \mathrm{C}$ and $25^{\circ} \mathrm{C}$

\begin{tabular}{|c|c|c|c|c|c|c|c|c|c|c|c|}
\hline \multicolumn{12}{|c|}{ Contents of organic acid $(\mathrm{mg} / \mathrm{mL})^{1)}$} \\
\hline & \multirow{7}{*}{$4^{\circ} \mathrm{C}$} & & 1 & 2 & 3 & 4 & 5 & 6 & 7 & 8 & 9 \\
\hline & & 0 & $0.32 \pm 0.07^{\mathrm{b} 2)}$ & $0.88 \pm 0.09^{\mathrm{ab}}$ & $0.36 \pm 0.08^{\mathrm{ND}}$ & $0.39 \pm 0.08^{b}$ & $4.16 \pm 1.32^{b}$ & $0.61 \pm 0.13^{b}$ & $0.009 \pm 0.002^{\mathrm{ND}}$ & $0.98 \pm 0.21^{\mathrm{bc}}$ & $\mathrm{ND}$ \\
\hline $\begin{array}{l}r \\
e \\
d\end{array}$ & & 4 & $0.30 \pm 0.05^{\mathrm{b}}$ & $0.80 \pm 0.12^{\mathrm{b}}$ & $0.20 \pm 0.06$ & $0.38 \pm 0.09^{b}$ & $3.77 \pm 1.05^{\mathrm{b}}$ & $0.51 \pm 0.11^{\mathrm{c}}$ & $0.008 \pm 0.001$ & $0.81 \pm 0.15^{\mathrm{c}}$ & $0.26 \pm 0.07^{\mathrm{ND}}$ \\
\hline $\mathrm{g}$ & & 8 & $0.32 \pm 0.07^{\mathrm{b}}$ & $0.86 \pm 0.21^{\mathrm{ab}}$ & $0.41 \pm 0.07$ & $0.40 \pm 0.12$ & $3.77 \pm 0.09^{b}$ & $0.50 \pm 0.08^{\mathrm{c}}$ & $0.007 \pm 0.001$ & $0.71 \pm 0.11^{\mathrm{c}}$ & $0.08 \pm 0.01$ \\
\hline n & & 12 & $0.31 \pm 0.04^{b}$ & $0.84 \pm 0.11^{\mathrm{ab}}$ & $0.39 \pm 0.04$ & $0.39 \pm 0.06^{b}$ & $3.85 \pm 1.14^{b}$ & $0.52 \pm 1.21^{\mathrm{c}}$ & $0.007 \pm 0.001$ & $0.72 \pm 0.06^{\mathrm{c}}$ & $0.08 \pm 0.01$ \\
\hline $\begin{array}{l}\mathrm{e} \\
\mathrm{e} \\
\mathrm{n}\end{array}$ & & 16 & $0.35 \pm 0.04^{\mathrm{ab}}$ & $0.95 \pm 0.17^{\mathrm{a}}$ & $0.48 \pm 0.09$ & $0.59 \pm 0.14^{\mathrm{a}}$ & $3.74 \pm 1.10^{b}$ & $0.56 \pm 0.09^{b}$ & $0.008 \pm 0.001$ & $0.78 \pm 0.14^{\mathrm{c}}$ & $0.42 \pm 0.13$ \\
\hline $\mathrm{g}$ & & 20 & $0.36 \pm 0.09^{\mathrm{ab}}$ & $0.98 \pm 0.115^{\mathrm{a}}$ & $0.55 \pm 0.12$ & $0.46 \pm 0.11^{\mathrm{ab}}$ & $3.51 \pm 0.08^{b}$ & $0.54 \pm 0.11^{b}$ & $0.008 \pm 0.002$ & $0.87 \pm 0.20^{\mathrm{bc}}$ & $1.43 \pm 0.08$ \\
\hline $\begin{array}{l}\text { MII } \\
a \\
a\end{array}$ & \multirow{6}{*}{$25^{\circ} \mathrm{C}$} & 0 & $0.35 \pm 0.04^{\mathrm{ab}}$ & $0.92 \pm 0.18^{\mathrm{a}}$ & $0.09 \pm 0.02$ & $0.58 \pm 0.13^{\mathrm{a}}$ & $2.18 \pm 0.57^{\mathrm{c}}$ & $0.42 \pm 0.08^{c}$ & $0.007 \pm 0.001$ & $0.92 \pm 0.13^{\mathrm{bc}}$ & $0.17 \pm 0.02$ \\
\hline$\stackrel{\mathrm{g}}{\mathrm{e}}$ & & 4 & $0.42 \pm 0.08^{\mathrm{a}}$ & $0.006 \pm 0.001^{\mathrm{c}}$ & $0.009 \pm 0.002$ & $0.12 \pm 0.02^{\mathrm{c}}$ & $5.29 \pm 1.33^{b}$ & $0.57 \pm 0.11^{b}$ & $\mathrm{ND}$ & $1.17 \pm 2.11^{b c}$ & $1.58 \pm 0.33$ \\
\hline $\begin{array}{l}0 \\
1\end{array}$ & & 8 & $0.43 \pm 0.05^{\mathrm{a}}$ & $0.001 \pm 0.000^{\mathrm{c}}$ & $0.01 \pm 0.003$ & $0.16 \pm 0.04$ & $8.17 \pm 1.72^{\mathrm{ab}}$ & $0.80 \pm 0.15^{\mathrm{ab}}$ & $\mathrm{ND}$ & $1.65 \pm 0.35^{b}$ & $2.35 \pm 0.82$ \\
\hline$\dot{i}$ & & 12 & $0.47 \pm 0.06^{\mathrm{a}}$ & $0.002 \pm 0.000^{c}$ & $0.01 \pm 0.002$ & $0.19 \pm 0.02^{\mathrm{c}}$ & $10.0 \pm 1.94^{a b}$ & $0.74 \pm 0.07^{\mathrm{ab}}$ & $\mathrm{ND}$ & $2.18 \pm 0.47^{\mathrm{ab}}$ & $2.85 \pm 0.17$ \\
\hline & & 16 & $0.45 \pm 0.05^{\mathrm{a}}$ & $0.002 \pm 0.000^{c}$ & $0.008 \pm 0.001$ & $0.19 \pm 0.04^{\mathrm{c}}$ & $12.8 \pm 2.34^{\mathrm{ab}}$ & $1.16 \pm 0.20^{\mathrm{a}}$ & $\mathrm{ND}$ & $2.62 \pm 0.67^{\mathrm{a}}$ & $3.34 \pm 1.07$ \\
\hline & & 20 & $0.46 \pm 0.04^{\mathrm{a}}$ & $0.002 \pm 0.000^{c}$ & $0.009 \pm 0.002$ & $0.17 \pm 0.02^{\mathrm{c}}$ & $19.9 \pm 3.65^{\mathrm{a}}$ & $0.49 \pm 0.08^{c}$ & $\mathrm{ND}$ & $2.89 \pm 0.18^{\mathrm{a}}$ & $3.62 \pm 0.08$ \\
\hline
\end{tabular}

${ }^{1)}$ 1, oxalic acid; 2, citric acid; 3, tartarric acid; 4, malic acid; 5, lactic acid; 6, acetic acid; 7, fumaric acid; 8, isobutyric acid; 9, butyric acid.

${ }^{2)}$ Values were expressed as the mean \pm SD $(n=3)$. ND, not detected.

Table 3. Change in free sugar and ethanol concentration in $2 \%$ red ginseng makgeolli during storage at $4^{\circ} \mathrm{C}$ and $25^{\circ} \mathrm{C}$

\begin{tabular}{|c|c|c|c|c|c|}
\hline \multicolumn{6}{|c|}{ Contents of free sugar and ethanol $(\mathrm{mg} / \mathrm{mL})$} \\
\hline \multirow{7}{*}{$4^{\circ} \mathrm{C}$} & Days & Sucrose & Glucose & Mannose & Ethanol \\
\hline & 0 & $2.83 \pm 0.31^{\text {al) }}$ & $4.44 \pm 0.33^{\mathrm{a}}$ & $1.38 \pm 0.14^{\mathrm{a}}$ & $72.34 \pm 9.52^{b}$ \\
\hline & 4 & $1.83 \pm 0.11^{\mathrm{ab}}$ & $3.00 \pm 0.41^{\mathrm{ab}}$ & $0.54 \pm 0.09^{\mathrm{b}}$ & $65.12 \pm 4.22^{\mathrm{c}}$ \\
\hline & 8 & $1.69 \pm 0.09^{\mathrm{ab}}$ & $2.94 \pm 0.34^{\mathrm{ab}}$ & $0.63 \pm 0.11^{\mathrm{b}}$ & $75.80 \pm 8.31^{\mathrm{b}}$ \\
\hline & 12 & $1.21 \pm 0.10^{\mathrm{b}}$ & $2.23 \pm 0.24^{b}$ & $0.49 \pm 0.09^{b}$ & $76.40 \pm 12.39$ \\
\hline & 16 & $1.01 \pm 0.07^{b}$ & $2.16 \pm 0.23^{b}$ & $0.59 \pm 0.07^{b}$ & $87.35 \pm 10.02^{\mathrm{ab}}$ \\
\hline & 20 & $0.81 \pm 0.11^{\mathrm{b}}$ & $1.97 \pm 0.18^{b}$ & $0.61 \pm 0.13^{\mathrm{b}}$ & $88.70 \pm 14.50^{\mathrm{ab}}$ \\
\hline \multirow{6}{*}{$25^{\circ} \mathrm{C}$} & 0 & $2.30 \pm 0.29^{\mathrm{a}}$ & $3.03 \pm 0.30^{\mathrm{ab}}$ & $0.65 \pm 0.10^{b}$ & $79.45 \pm 6.94^{b}$ \\
\hline & 4 & $0.14 \pm 0.02^{c}$ & $0.17 \pm 0.03^{\mathrm{c}}$ & $0.29 \pm 0.04^{b}$ & $91.92 \pm 15.00^{\mathrm{a}}$ \\
\hline & 8 & $\mathrm{ND}$ & $0.14 \pm 0.01^{\mathrm{c}}$ & $0.07 \pm 0.01^{\mathrm{c}}$ & $97.06 \pm 9.38^{\mathrm{a}}$ \\
\hline & 12 & $\mathrm{ND}$ & $\mathrm{ND}$ & ND & $94.30 \pm 13.33^{\mathrm{a}}$ \\
\hline & 16 & $\mathrm{ND}$ & ND & ND & $93.92 \pm 7.14^{\mathrm{a}}$ \\
\hline & 20 & $\mathrm{ND}$ & $\mathrm{ND}$ & $\mathrm{ND}$ & $95.59 \pm 10.31^{\mathrm{a}}$ \\
\hline
\end{tabular}

${ }^{1)}$ Values were expressed as the mean $\pm \mathrm{SD}(\mathrm{n}=3)$. ND, not detected.
변화는 Fig. 3 및 4에서 보는 바와 같다. 홍삼전분을 이용한 막걸리는 $4^{\circ} \mathrm{C}$ 에서 4 일 저장한 경우 $\mathrm{pH} 4.3$ 에서 저장 8 일경 에는 $\mathrm{pH} 3.8$ 로 떨어지면서 저장기간 동안 서서히 감소를 보였으며 블루베리를 첨가한 막걸리(26)와 멥쌀로 빚은 탁 주(27)의 $\mathrm{pH}$ 가 발효 후에 $3.5 \sim 3.6$ 로 보고하여 본 연구의 $\mathrm{PH}$ 결과와 유사한 수치를 나타냈다. 막걸리의 $\mathrm{pH}$ 는 함유하 고 있는 유기산 종류 및 농도, 기타 산유래 물질에 의해 영향을 받는 것으로 나타났다(28). $25^{\circ} \mathrm{C}$ 에서 저장한 경우, $\mathrm{pH}$ 4.6 3.2 수준으로 $4^{\circ} \mathrm{C}$ 저장 온도보다 $25^{\circ} \mathrm{C}$ 온도에서 $\mathrm{pH}$ 가 낮게 관찰 되었다. 한편 총산은 막걸리의 관능적 요소와 제품 품질에 영향을 주는 중요한 지표로서 발효 이상으로 인하여 $\mathrm{pH}$ 가 지나치게 높을 경우 감미의 소실과 함께 산미 와 고미가 상대적으로 증가하게 되어 제품의 관능적 품질을 저하(29)시킨다. 홍삼전분을 이용한 막걸리의 경우는 제품 내 효모 및 유산균등에 의하여 저장 중에도 미세하게 발효 가 진행되어 발효 산물인 각종 유기산 및 기타 산 물질을 생산하고 그리고 홍삼전분에 포함되어 있는 유기산등에 의하여 총산 함량이 증가한 것으로 사료된다. 따라서 홍삼 


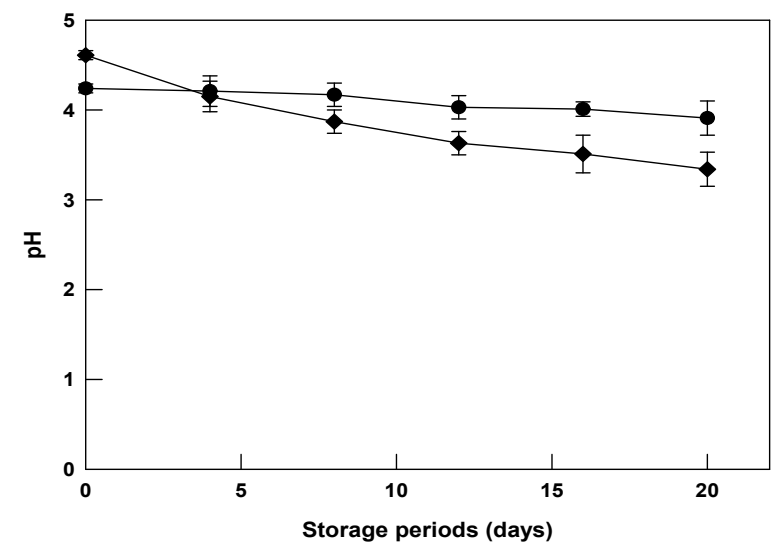

Fig. 3. Change in $\mathrm{pH}$ of $2 \%$ red ginseng Makgeolli during storage at $4{ }^{\circ} \mathrm{C}(O)$ and $25^{\circ} \mathrm{C}(>)$.

Values with varying superscripts in the same row are significantly different $(\mathrm{p}<0.05)$ among groups in Tukey's test.

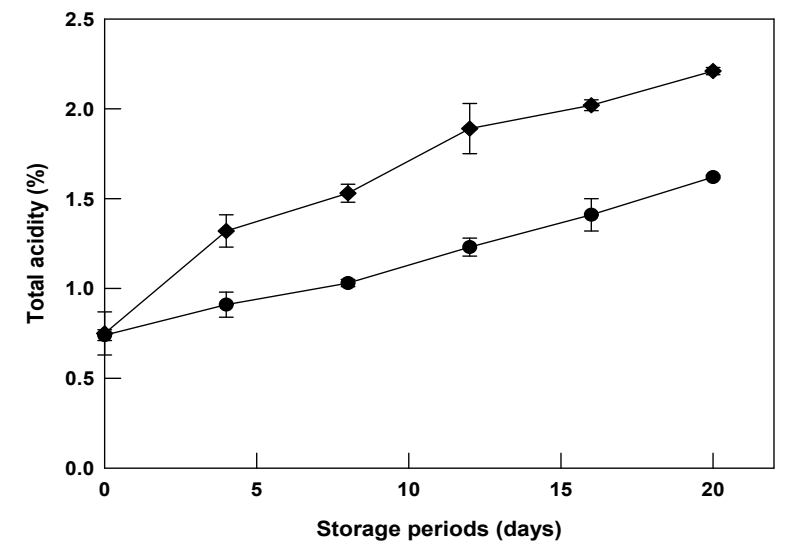

Fig. 4. Changes in total acidity of $2 \%$ red ginseng Makgeolli during storage at $4^{\circ} \mathrm{C}(\boldsymbol{)})$ and $25^{\circ} \mathrm{C}(\nabla)$.

Values with varying superscripts in the same row are significantly different $(p<0.05)$ among groups in Tukey's test.

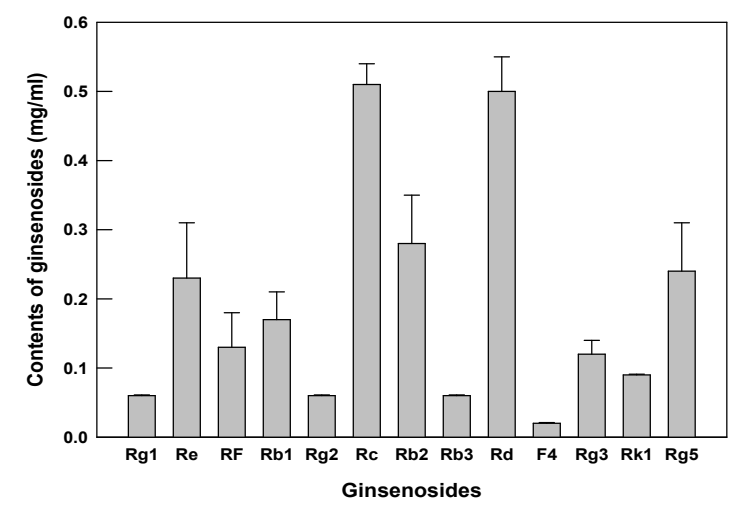

Fig. 5. Contents of ginsenoside in 2\% red ginseng Makgeolli. Values were expressed as the mean $\pm \mathrm{SD}(\mathrm{n}=3)$.
전분을 이용한 막걸리의 제조시에 총산이 증가할 가능성이 높고 제품의 산미가 강한 것으로 나타났다. 따라서 제품의 제조시에 발효 기간과 온도를 확립해야 한다. 그러나 저장 기간 중 총산의 증가는 저장성을 높여주는 요인으로 작용하 므로 본 연구에서 개발한 막걸리의 경우에는 부패할 가능성 은 매우 낮은 것으로 분석되었다.

\section{진세노사이드 분석}

홍삼전분 막걸리 제조 방법에 따라 제조 후 3 일간 숙성시 켜 완성된 막걸리의 진세노사이드 함량 분석 결과는 Fig. 5 와 같다. 홍삼전분을 이용한 막걸리의 총 진세노사이드 함량은 $2.47 \mathrm{mg} / \mathrm{mL}$ 이며 $\mathrm{Rg} 1, \mathrm{Rb} 1$ 그리고 $\mathrm{Rg} 3$ 의 함량은 $0.35 \mathrm{mg} / \mathrm{mL}$ 으로 측정되었다. 인삼사포닌(ginsenoside)은 생화학 및 약리작용을 나타내는 인삼의 주요한 성분이라고 알려져 있으며(30) 인삼에 열이나 압력을 가해서 만들어진 홍삼은 ginsenoside $\mathrm{Rg} 1, \mathrm{Rg} 3, \mathrm{Rb} 1, \mathrm{Rh} 1$ 이 소량 생성되는데 이 특유성분이 항암작용(31), 두뇌기능 및 뇌신경세포 보호 작용(32), 항혈전작용(33) 등을 나타낸다고 알려져 있어 홍 삼의 면역증진 활성 등의 기능성 역할을 예상할 수 있다.

\section{요 약}

본 연구에서 사용한 홍삼 전분은 홍삼 농축액 제조 공정 에서 발생하는 부산물중 하나로 현재까지는 특별한 활용도 가 없었다. 하지만 홍삼 농축액 제조 과정에서 발생되는 홍삼 유래의 물질로 홍삼의 유효 성분인 진세노사이드 및 각종 유리당, 탄수화물 등이 풍부한 안전한 소재로서의 가 능성을 알아보고자 하였다. 홍삼전분을 이용한 새로운 홍 삼막걸리의 차별화를 위하여 제품의 진세노사이드 함량, 유기산, 유리당, 효모수 등을 분석하였다. 효모 생균수의 변화 조사결과 $4^{\circ} \mathrm{C}$ 에서 저장하였을 때는 저장 20 일까지 효모 균수에 큰 변화가 없었지만 $25^{\circ} \mathrm{C}$ 저장에서는 저장 20 일에 초기 효모균수의 약 $75 \%$ 가 감소되었다. 유기산분석 결과 막걸리에서는 lactic acid가 $4.16 \mathrm{mg} / \mathrm{mL}$ 의 농도로 가장 많았으며, 그 다음으로는 citric acid $0.88 \mathrm{mg} / \mathrm{mL}$, malic acid $0.39 \mathrm{mg} / \mathrm{mL}$ 의 순서로 많았다. 저장 초기에는 malic acid의 함량이 $4^{\circ} \mathrm{C}$ 및 $25^{\circ}$ C에서 $0.39 \mathrm{mg} / \mathrm{mL}$ 와 $0.58 \mathrm{mg} / \mathrm{mL}$ 이었으 나 저장일이 20 일 경과하였을 때에는 $0.46 \mathrm{mg} / \mathrm{mL}$ 그리고 $0.17 \mathrm{mg} / \mathrm{mL}$ 으로 측정되었고 대부분의 유기산은 저장기간 에 관계없이 변화가 크게 나타나지 않았으나 butyric acid는 증가를 보였다. 20일 경에 lactic acid와 isobutyric acid는 감소하였으며 다른 종류의 유기산은 증가를 보였다. 유리 당 분석결과 glucose가 $4.4 \mathrm{mg} / \mathrm{mL}$, sucrose $2.8 \mathrm{mg} / \mathrm{mL}$ 그리 고 mannose $1.4 \mathrm{mg} / \mathrm{mL}$ 으로 막걸리의 주 구성당으로 분석 되었으며 저장기간이 지속되면서 sucrose, glucose, mannose 의 함량은 감소를 보여 알콜 발효의 주요 기질로 사용되었 
음을 보여주었다. 저장 4 8일 이후부터는 당이 급격히 감소 하였으며 8 일 이후부터는 큰 차이를 보이지 않았다. 이것은 저장 중 당분이 알콜과 탄산가스로 분해되었기 때문에 함량 이 감소한 보여진다. $4^{\circ} \mathrm{C}$ 에서 저장시, 일반적인 유통기간보 다(10일) 긴 20 일 동안 유리당의 변화를 보였으며 유리당은 12 일 경에 sucrose, glucose와 mannose의 양은 $1 / 2$ 으로 감소 하였다. 총산 및 $\mathrm{pH}$ 분석결과 각 저장온도에서 저장기간에 따른 $\mathrm{pH}$ 의 변화는, $4^{\circ} \mathrm{C}$ 에서 저장한 경우, 저장 4 일경 $\mathrm{pH}$ 4.3 에서 8 일경 $\mathrm{pH} 3.8$ 로 떨어지면서 저장기간 동안 서서히 감소되었다. $25^{\circ} \mathrm{C}$ 에서 저장한 경우, $\mathrm{pH}$ 4.6 3.2 수준으로 $4^{\circ} \mathrm{C}$ 저장 온도보다 $25^{\circ} \mathrm{C}$ 온도에서 $\mathrm{pH}$ 가 낮게 관찰 되었고 진세노사이드 분석결과 함량은 $2.47 \mathrm{mg} / \mathrm{g}$ 으로 측정되었다.

\section{감사의 글}

본 연구는 2013년 농촌진흥청 “신 기능성 농식품 및 부가 가치 향상 기술 개발” 사업(과제번호 : PJ009126)의 지원에 의해 이루어진 연구이며, 이에 감사드립니다.

\section{References}

1. Woo SM, Shin JS, Seong JH, Yeo SH, Choi JH, Kim TY, Jeong YJ (2010) Quality characteristics of brown rice Takju by different Nuruks. J Korean Soc Food Sci Nutr, 39, 301-307

2. Kim AR, Lee SY, Kim KBWR, Song EJ, Kim JH, Kim MJ, Ji KW, Ahn IS, Ahn DH (2008) Effect of Glycyrthiza uralensis on shelf-life and quality of takju. Korean J Food Sci Technol, 40, 194-200

3. An BH (1995) Study on problems of quality improvement of Korean tradional liquor. Bull Food Technol, 8, 130-137

4. Jang JH (1989) History of Korean brew alcoholic beverages. Korean J Dietary Culture, 4, 271-274

5. Yoo TJ (1981) Korean famous wine. Central New Book, Seoul, p 96

6. Kim JY, Sung KW, Bae HW, Yi YH (2007) pH, acidity, color, reducing sugar, total sugar, alcohol and organoleptic characteristics of puffed rice powder added takju during fermentation. Korean J Food Sci Technol, $39,266-271$

7. Lee CH (1993) History of Korean liquor. Bioindustry News, 6, 4058-4061

8. Seo WT, Cho HK, Lee JY, Kim B, Cho KM (2012) Quality characteristics of wheat-rice makgeolli by making of rice nuruk prepared by Rhizopus oryzae CCSO1.
Korean J Microbiol, 48, 147-155

9. Kim GM, Jung WJ, Shin JH, Kang MJ, Sung NJ (2011) Preparation and quality characteristics of makgeolli made with black garlic extract and sulgidduk. J Korean Soc Food Sci Nut, 40, 759-766

10. Lee HS (2000) Quality characteristics of takju using nuruk during fermentation. MS Thesis, Seoul Women's University, Seoul, p 5-9

11. Lee GH (1994) The properties and new technologies of Korean medicinal wine and Takju. J Microbiol Biotechnol, 7, 4036-4046

12. Wang SJ, Lee HJ, Cho JY, Park KH, Moon JH (2012) Isolation and identification of antioxidants from makgeolli. Korean J Food Sci Technol, 44, 14-20

13. Jang SK, Kim JH, Chung YS, Ahn DC, Kang MJ, Lee DG, Kim SH (1994) An experimental study on the effect of immunopotential and the anticancer effect of red ginseng extract. J Ginseng Res, 18, 151-159

14. Lee EJ, Ko E, Lee J, Rho S, Ko S, Shin MK, Min BI, Hong MC, Kim SY, Bae H (2004) Ginsenoside Rg1 enhances $\mathrm{CD} 4(+)$ T-cell activities and modulates Th1/Th2 differentiation. Int Immunopharmacol, 4, 235-244

15. Kim YS, Lee H, Kim DY, Kim SY, Lee WK, Lee SM, Park JD, Shon MY (2013) Cultivation of lactic acid bacteria for the development of probiotic products using red ginseng starch. J East Asian Soc Dietary Life, 23, 818-826

16. Chung DH (2004) The developmental history of Korean alcoholic beverages. Shinkwang Publishing Co, Seoul, Korea, p 271-298

17. Sim KH, Sung NK, Choi JH, Kang KS (1989) Changes in major components of Japanese apricot during ripening. J Korean Soc Food Nutr, 18, 101-108

18. Hu UD, HA JH, Suk HM, Nam YJ, Shin DH (1987) Analysis and improvement of flavors and taste components of traditional foods. Food Res Report, p 14

19. Jeong, JW, Park KJ, Kim MH, Kim DS (2006) Changes in quality of spray-dried and freeze-dried Takju powder during storage. Korean J Food Sci Technol, 38, 513-520

20. Seo MY, Lee JK, Ahn BH, Cha SK (2005) The changes of microflora during the fermentation of Takju and Yakju. Korean J Food Sci Technol, 37, 61-66

21. Choi SH, Kim OK, Lee MW (1992) A study on the gas chromatographic analysis of alcohols and organic acids during takju fermentation. Korean J Food Sci Technol, 24, 272-278 
22. Laztity L (1990) Phytic acid in cereal technology. AACC, $\operatorname{Vol}(\mathrm{X}), 309$

23. Toma RB, Tabekhia MM (1979) Changes in mineral elements and phytic acid contents during cooking of three california rice varieties. J Food Sci, 44, 619-621

24. Beal L, Metha T (1985) Zinc and phytate distribution in peas. J Food Sci, 50, 96-100

25. Cho HK, Seo WT, Lee JY, Cho KM (2012) Quality characteristics of cereal Makgeolli rice Nuruk prepared Rhizopus oryzae CCS01. J Korean Soc Food Sci Nutr, 41, 1002-1008

26. Jeon MH, Lee WJ (2011) Characteristics of blueberry added Makgeolli. J Korean Soc Food Sci Nutr, 40, 444-449

27. Lee JS, Lee TS, Noh BS, Park SO (1996) Quality characteristics of mash of Takju prepared by different raw materials. Korean. J Food Sci Technol, 28, 330-336

28. Song JC, Park HJ, Shin WC (1997) Change of takju qualities by addition of cyclodextrin during the brewing and aging. Korean J Food Sci Technol, 29, 895-900
29. Lee SS, Kim KS, Eom AH, Sung CK, Hong IP (2002) Production of Korean traditional rice-wines made from cultures of the single fungal isolates under laboratory conditions. Korean J Mycol, 30, 61-65

30. Han ST, Whang WK, Kim IH, Yang BW (2005) Analysis of ginsenosides of black ginseng. Yakhak Hoeji, 49, 490-494

31. Keum YS, Park, KK, Lee JM, Chun KS, Park JH, Lee SK, Kwon H, Surh YJ (2000) Antioxidant and anti-tumor promoting activities of the methanol extract of heat-processed ginseng. Cancer Lett, 150, 41-48

32. Bao HY, Zhang J, Yeo SJ, Myung CS, Kim HM, Kim JM, Park JH, Cho JS, Kang JS (2005) Memory enhancing and neuroprotective effects of selected ginsenosides. Arch Pharm Res, 28, 335-342

33. Jung KY, Kim DS, Oh SR, Lee IS, Lee JJ, Park JD, Kim SI, Lee HK (1998) Platelet activating factor antagonist activity of ginsenosides. Biol Pharm Bull, 21, 79 